\title{
Biological studies and assessment of the exploitation status of the green tiger shrimp Penaeus semisulcatus from Jizan Area, Red Sea
}

\section{Lafi S Alsolami and Hassan A Jastania}

Faculty of Marine Sciences, Marine Biology Dept., King Abdulaziz University, Jeddah, Saudi Arabia

\section{lalsulami@kau.edu.sa}

\begin{abstract}
The present study was undertaken to investigate some biological aspects of the green tiger shrimp Penaeus semisulcatus in order to provide the biological information required for its proper management of the fishery in Jizan area, Red Sea. Growth parameters were calculated as $(\mathrm{L} \infty=94.40 ; \mathrm{K}=0.81$; to $=-0.2)$; maximum age tmax $=3.7037$ years; growth performance indices $\left(\varnothing \mathrm{L}=3.86\right.$; $\varnothing_{\mathrm{wt}}$ = 1.36). Carapace length at which $P$. semisulcatus females attained $50 \%$ of maturity was $38 \mathrm{~mm}$. The annual mortality coefficients were $(Z=3.124$ year-1; $\mathrm{M}$ $=1.163$ year-1 \& F = 1.961 year-1). Carapace length and age at first capture were $35.73 \mathrm{~mm}$ and 0.387 year, while carapace length and age at recruitment were $28.52 \mathrm{~mm}$ and 0.24 year, respectively. The length at first sexual maturity was found to be $38 \mathrm{~mm}$, while the carapace length at first capture L50 was estimated as $35.73 \mathrm{~mm}$. This indicates that there is a poor opportunity for the recruits of $P$. semisulcatus in Jizan area to spawn before fishing which is considered an important factor that would lead to overexploitation the stock. The estimated exploitation ratio $(0.628)$ was higher than $E_{\max }(0.581)$ which indicates that, the fisheries status of this species under study is in overexploited.
\end{abstract}

Keywords: Tiger shrimp, Penaeus semisulcatus, shrimp, biology, fisheries, growth, Jizan, Red Sea. 


\section{Introduction}

The green tiger shrimp Peneaus semisulcatus (De Haan, 1844) dominates the commercial catches from trawlers operated in both the Red Sea and the Arabian Gulf fishing grounds (Boerema, 1969). Although extensive studies on $P$. semisulcatus have been carried out in the Gulf region Al-Atter and Ikenous (1974); Price and Jones, (1975); Mohamed et al., (1981); van Zaling, (1984); Buqis and Abdulqader ( 1993 \& 1994), little information is available on this species in the Red Sea as Ghamrawy (1988 \& 1990) and Abdallah and Abushusha (2003) which stated that, the catch of $P$. semisulcatus showed a sharp decline over the six fishing seasons from 1995/1996 to 2000/2001.

In Saudi Arabian Red Sea water, the distribution of $P$. semisulcatus is associated with the extension of the continental shelf where the bottom is muddy, especially in three regions; the Jizan area in the south (as shown in Fig., 1), Al-Qunfedah area, and in AlKhoribah area in the far north, its resources is concentrated and fished commercially (PERSGA-GEF 2002).

Jizan region which extends from Latitude $17^{\circ} 40^{\prime} \mathrm{N}$ southwards to the Yemeni border covering an estimated total area of about 10,000 square kilometers consider the most important fishing ground in Saudia Arabia, where more than $90 \%$ of the shrimp trawlers operate Abdallah and Abu-Shoushah (2003).

The aim of the present study was to study some biological aspects of $P$. semisulcatus including gonads maturity and growth and to assess the current exploitation status of this target species in Jizan fisheries.

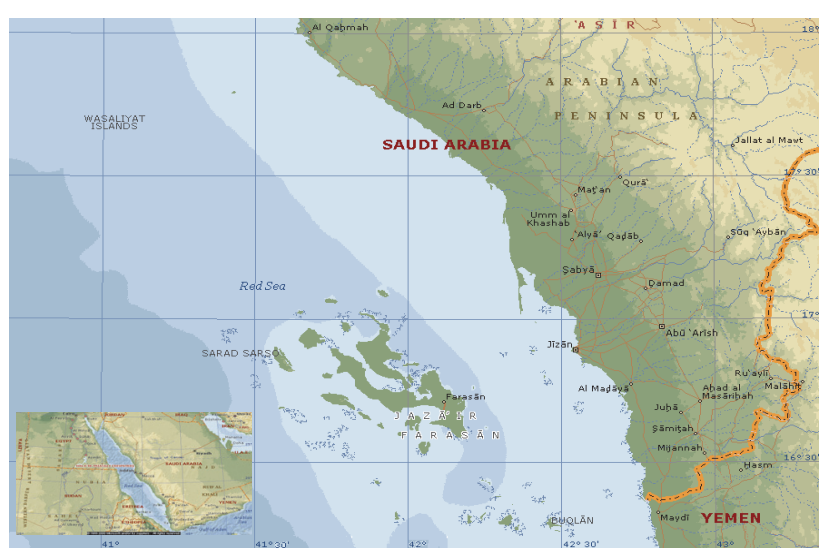

Fig. (1): A map showing the study area off the Saudi coast.

\section{Materials and Methods}

A total of 652 individuals, 342 females and W. males of P. semisulcatus ranging from 20 to $85 \mathrm{~mm}$ carapace length (CL) were collected from shrimp trawlers at Jizan landing site twice a month during the study period (2015 2016). Shrimp species were identified according to the FAO species identification sheets, Fischer and Blanchiceds (1984). Females and males were sorted. All 
individuals were weighed to the nearest $0.01 \mathrm{~g}$ and measured the carapace length (CL) from post the orbital margin to the posterior end of the mid-dorsal line of the carapace using a Vernier caliper.

Length weight relationship was estimated according to Le Cren (1951), while the condition factor was calculated according to Hile (1936). Carapace length frequency distribution of $P$. semisulcatus was determined and the percentage of occurrence of each length class was investigated.

The monthly Carapace length frequency distributions were analyzed by ELEFAN program Pauly and David (1981) incorporated in LFDA software for the estimation of growth parameters $\left(\mathrm{L}_{\infty}, \mathrm{K} \& \mathrm{t}_{\mathrm{o}}\right)$ for the sexes combined, where $L_{\infty}$ is the asymptotic total length, $\mathrm{K}$ is the curvature parameter and $t_{o}$ is the Age at length zero. The maximum age was obtained according to Pauly (1981) equation. According to Moreau et al. (1986), the following two equations were adopted to estimate the growth performance of length and weight for the species under study.

Growth performance in length: $\Phi_{\mathrm{L}}=\mathrm{Log} \mathrm{K}+2$ $(\log \mathrm{L} \infty)$
Growth performance in weight: $\Phi_{\mathrm{W}}=\log \mathrm{K}+$ 2/3 (Log $\mathrm{W} \infty)$

The gonadal maturity of $P$. semisulcatus was determined by visual examination of the maturity stages of the female gonads (ovaries) based on the color and size of ovaries of the collected samples Shaikhmahmud, (1961), Rao. (1968) and Metin et al.( 1999) to estimate the length at first sexual maturity.

The instantaneous total mortality coefficient " $Z$ " of the species under study in Jizan area was obtained by the cumulated catch curve which is based on length composition data Jones and van Zalinge (1981). Natural mortality (M) was derived through the empirical equation of Pauly (1980) considering the mean annual habitat temperature as $29.9^{\circ} \mathrm{C}$ world sea temperature,( 2016). Instantaneous fishing mortality values "F" can be easily calculated by subtracting "M" from "Z" Beverton and Holt (1957).

Length and age at first capture $\left(\mathrm{L}_{\mathrm{c}} \& \mathrm{t}_{\mathrm{c}}\right)$ were investigated from the equation of Beverton and Holt (1956 \& 1957). Length and Age at recruitment $\left(L_{r} \& t_{r}\right)$ were estimated by applying Von Bertalanffy growth equation. 
The current exploitation rate "E" was computed according to the formula of Gulland (1971): $E=F / Z$. The relative yield per recruit "Y/R" and relative biomass per recruit " $\mathrm{B} / \mathrm{R}$ " were estimated by using the model of Beverton and Holt (1956) as modified by Pauly and Soriano (1986) and incorporated in the FiSAT software package. Relevant values of exploitation rates $\left(\mathrm{E}_{10}, \mathrm{E}_{50} \& \mathrm{E}_{\max }\right)$ were estimated to assess the rate of exploitation of $P$. semisulcatus in Jizan area.

\section{Results}

Six shrimp species were recorded in the commercial landing of Jizan region. Two of them, Penaeus semisulcatus and Metapenaeus monoceros (Fabricius, 1798) are the most commercially important species while the others, Penaeus japonicas (Bate, 1798), Penaeus monodon (Fabricius, 1798), Penaeus latisulcatus (Kishinouye, 1896) and Trachypenaeus curvirostris are landed in very small quantities. This study shows that, the green tiger shrimp constitutes the majority of the annual total shrimp catch taken by bottom trawlers in the Jizan area as its abundance percentage ranged from 84.5 $\%$ to $93.24 \%$ during the years from 2010 to 2016.

\section{Carapace length total weight relationship:}

The Carapace length - weight relationship for combined sexes of $P$. semisulcatus in Jizan area (Fig. 2) is represented by the formula: $\mathrm{W}=0.0008 \mathrm{~L}$ ${ }^{2.6694}, \mathrm{R}^{2}=0.9242$.

\section{Length frequency distribution}

Length frequency data of $P$. Semisulcatus was arranged in one mm length intervals and the results are expressed the numbers as percentages (Table1). Carapace length groups of $P$. Semisulcatus covered a length range between $20 \mathrm{~mm}$ to $85 \mathrm{~mm}$; the majority of individuals were in length groups between $40 \mathrm{~mm}$ and $60 \mathrm{~mm}$ and the dominant one is with $50 \mathrm{~mm}(10 \%)$.

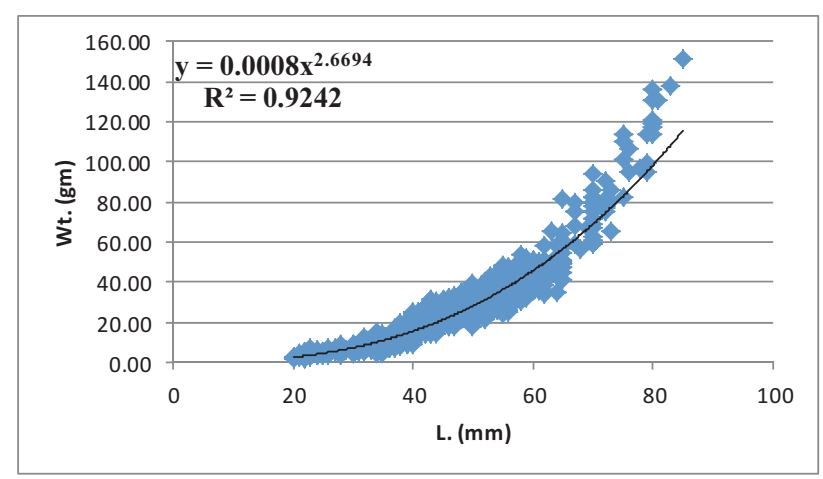

Fig. (2): Carapace length-total weight relationship of $\boldsymbol{P}$. semisulcatus in Jizan area. 
Table (6): Length frequency distribution of $P$. Semisulcatus between 2015/2016.

\begin{tabular}{|c|c|c|c|c|c|}
\hline Carapace Length $(\mathrm{mm})$ & No. & $\%$ & Carapace Length (mm) & No. & $\%$ \\
\hline 20 & 5 & 0.77 & 50 & 65 & 9.97 \\
\hline 21 & 3 & 0.46 & 51 & 12 & 1.84 \\
\hline 22 & 5 & 0.77 & 52 & 25 & 3.83 \\
\hline 23 & 16 & 2.45 & 53 & 33 & 5.06 \\
\hline 24 & 6 & 0.92 & 54 & 15 & 2.30 \\
\hline 25 & 3 & 0.46 & 55 & 23 & 3.53 \\
\hline 26 & 3 & 0.46 & 56 & 7 & 1.07 \\
\hline 27 & 2 & 0.31 & 57 & 8 & 1.23 \\
\hline 28 & 5 & 0.77 & 58 & 14 & 2.15 \\
\hline 29 & 1 & 0.15 & 59 & 7 & 1.07 \\
\hline 30 & 23 & 3.53 & 60 & 20 & 3.07 \\
\hline 31 & 8 & 1.23 & 61 & 5 & 0.77 \\
\hline 32 & 18 & 2.76 & 62 & 17 & 2.61 \\
\hline 33 & 12 & 1.84 & 63 & 5 & 0.77 \\
\hline 34 & 14 & 2.15 & 64 & 5 & 0.77 \\
\hline 35 & 12 & 1.84 & 65 & 15 & 2.30 \\
\hline 36 & 6 & 0.92 & 67 & 4 & 0.61 \\
\hline 37 & 5 & 0.77 & 68 & 1 & 0.15 \\
\hline 38 & 6 & 0.92 & 69 & 1 & 0.15 \\
\hline 39 & 5 & 0.77 & 70 & 17 & 2.61 \\
\hline 40 & 15 & 2.30 & 71 & 6 & 0.92 \\
\hline 41 & 7 & 1.07 & 73 & 3 & 0.46 \\
\hline 42 & 17 & 2.61 & 75 & 4 & 0.61 \\
\hline 43 & 38 & 5.83 & 76 & 2 & 0.31 \\
\hline 44 & 24 & 3.68 & 78 & 1 & 0.15 \\
\hline 45 & 18 & 2.76 & 79 & 3 & 0.46 \\
\hline 46 & 13 & 1.99 & 80 & 7 & 1.07 \\
\hline 47 & 12 & 1.84 & 81 & 1 & 0.15 \\
\hline 48 & 11 & 1.69 & 83 & 1 & 0.15 \\
\hline 49 & 11 & 1.69 & 85 & 1 & 0.15 \\
\hline
\end{tabular}




\section{Growth parameters}

The parameters of Von Bertalanffy growth model of $P$. semisulcatus in Jizan area were

Growth Curve $=$ Pauly Seasonal. Linf $=94.40 . K=0.81$. Tzero $=-0.20$.

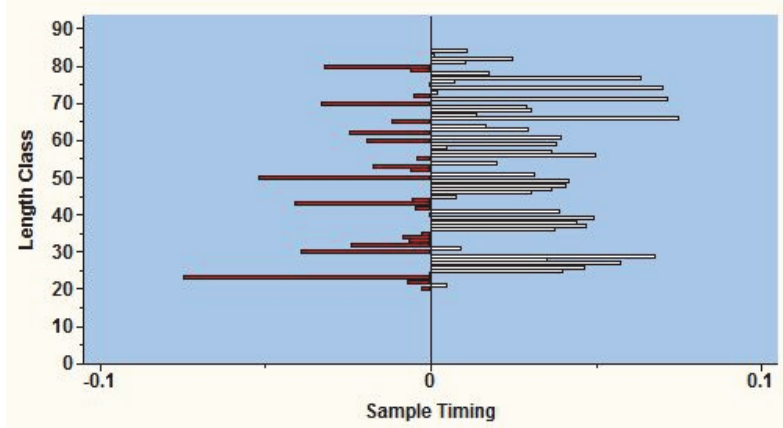

Fig. (3): Growth parameters $\left(L_{\infty}, K \& t_{0}\right)$ for $P$. semisulcatus in Jizan area

The maximum age $\left(t_{\max }\right)$ was computed as 3.70 year. The growth performance indices $\left(\varnothing_{\mathrm{L}}\right.$ and $\varnothing_{\mathrm{wt}}$ ) could be considered a good index of shrimps growth. The growth performance in length and weight were 3.86 and 1.36 respectively.

\section{Length at first sexual maturity $\left(\mathrm{L}_{\mathrm{m} 50}\right)$}

Penaeus semisulcatus females less than $26 \mathrm{~mm}$ of carapace length were collectively immature (Fig. 4). Larger individuals showed an increase in the frequency of mature specimens and all females longer estimated to be as follows: $\mathrm{L}_{\infty}=94.40 \mathrm{~mm}, \mathrm{~K}$ $=0.81$ year $^{-1} \& \mathrm{t}_{\mathrm{o}}=-0.20$ year $^{-1}$, as shown in Figure (3).

than $46 \mathrm{~mm}$ carapace length were fully mature. It is also clear that females of $P$. semisulcatus attained its $50 \%$ of sexual maturity at carapace length of $38 \mathrm{~mm}$. as shown in Fig. (4).

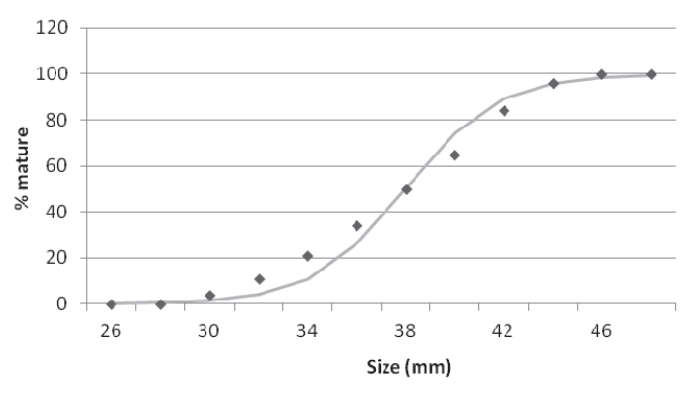

Fig. (4): Carapace length ( $\mathrm{mm})$ at first sexual maturity for females $P$. semisulcatus.

\section{Instantaneous mortality coefficients}

The instantaneous natural mortality coefficient (M) for P. semisulcatus in Jizan area was estimated as 1.163 year $^{-1}$. The estimated total mortality coefficient depends on the cumulated catch curve which is based on length composition data Jones and van Zalinge, (1981) was 3.124 year $^{-1}$ (as shown 
in Fig. 5). Fishing mortality coefficient was found to be 1.961 year $^{-1}$.

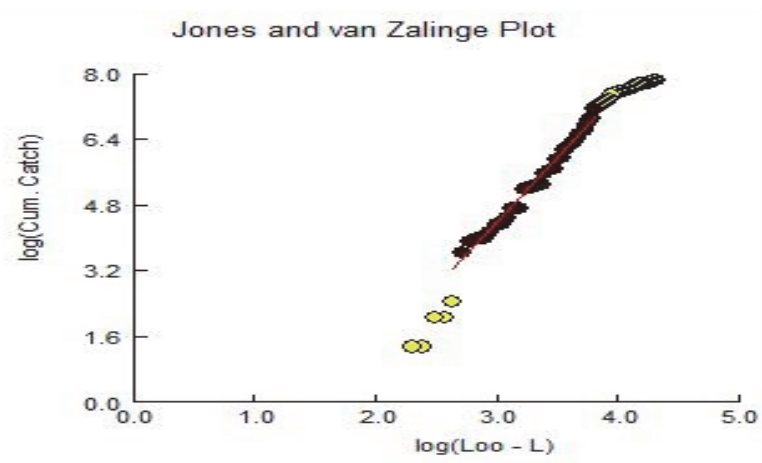

Fig. (5): Jones and van Zalinge plot for $P$. semisulcatus.

\section{Carapace length and age at first capture and at recruitment}

The carapace length at first capture $\left(\mathrm{L}_{50}\right)$ was estimated as $35.73 \mathrm{~mm}$. In addition, the $t_{c}$ was 0.387 year. Length at recruitment " $\mathrm{L}_{r}$ " was $28.52 \mathrm{~mm}$, where the age at recruitment $\mathrm{t}_{\mathrm{r}}$ was 0.24 year.

\section{Current Exploitation rate}

In the present study the exploitation ratio of $P$. semisulcatus in Jizan area was found to be 0.628 .

Relative yield / recruit, biomass / recruit and prediction of the maximum exploitation ratio:
Relevant values of exploitation rates were $\left(\mathrm{E}_{10}=0.502, \mathrm{E}_{50}=0.328 \& \mathrm{E}_{\max }=0.581\right)$ where; $E_{10}$ is the exploitation rate at which the marginal increase of $Y^{\prime} / R$ is $1 / 10$ of its value at $\mathrm{E}=0 ; \mathrm{E}_{50}$ is the exploitation rate under which the stock has been reduced to $50 \%$ of its unexploited biomass; and $E_{\max }$ is the exploitation rate which produces maximum yield. The results showed that, $\mathrm{E}_{\text {cur }}(0.628)$ was higher than $\mathrm{E}_{10}(0.502)$ and $\mathrm{E}_{\max }(0.581)$ which indicates that, the fisheries status of this species suffer from overexploitation (Fig. 6).

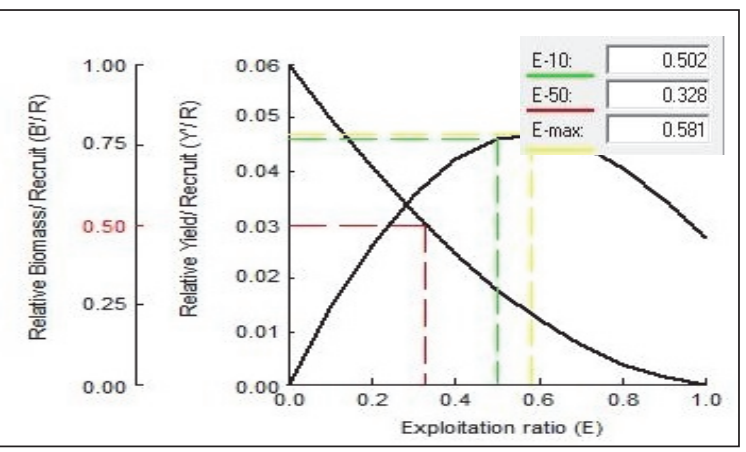

Fig. (6): Relative yield / recruit $\left(Y^{\prime} / R\right)$ and relative biomass /recruit ( $\left.\mathrm{B}^{\prime} / \mathrm{R}\right)$ for $P$. semisulcatus.

\section{Discussion}

The asymptotic total lengths for combined sexes $\left(L_{\infty}=94.4\right)$ were higher than most of the corresponding values $(54.3,37.0 \mathrm{~mm}$ during the fishing season 1985/86; 49.5, $36.1 \mathrm{~mm}$ during 1986/87; 52.1, $36.8 \mathrm{~mm}$ during 1987/88; 50.9, $37.1 \mathrm{~mm}$ during 1988/89 \& 
49.0, $36.1 \mathrm{~mm}$ during 1989/90) that estimated by Hussain et. al., (1996). This can be attributed to that maximum observed size of shrimp caught in this study were greatly higher than those of other localities. The above mentioned different values of females and males asymptotic carapace lengths indicate that the specifications of the trawl fishing gear (especially, the code end mesh size) contribute higher effort on females than males.

It is also clear that female $P$. semisulcatus attained its $50 \%$ of sexual maturity at carapace length of $38 \mathrm{~mm}$. On the other hand, Niamaimandi, et al. (2008) investigated the reproductive cycle of the green tiger prawn $P$. semisulcatus the coastal waters of Bushehr, Iran, Persian Gulf. They found that the minimum size at maturity was $24 \mathrm{~mm}$ carapace length (CL), and 50\% were mature at $40 \mathrm{~mm}$ CL.

The length or age at first sexual maturity helps in the determination of the minimum legal size that must be avoided in fishing in order to protect an adequate spawning stock and ensure at least one spawning for the mature individuals Zaki et al. (1995). The length at first sexual maturity of $P$. semisulcatus in Jizan area was found to be 38 mm., while the carapace length at first capture $\mathrm{L}_{50}$ was estimated as $35.73 \mathrm{~mm}$ which indicates that, there is a poor opportunity for the recruits of $P$. semisulcatus in Jizan area to spawn before fishing which is considered an important factor that leads to the overexploitation of the stock.

The annual mortality coefficients of $P$. semisulcatus were $\left(\mathrm{Z}=3.124\right.$ year $^{-1}, \mathrm{M}=$ 1.163 year $^{-1} \& \mathrm{~F}=1.961$ year-. These results are quite consistent with the findings of Mohamed and El-Aiatt, (2012) who studied the population dynamics and fisheries management of $P$. semisulcatus in Bardawil lagoon, North Sinai, Egypt. They estimated the mortalities coefficients as; total (Z: 3.24 \& $\left.5.34 \mathrm{yr}^{-1}\right)$, natural $\left(\mathrm{M}: 1.05 \& 1.16 \mathrm{yr}^{-1}\right)$ and fishing mortality (F: $2.18 \& 4.17 \mathrm{yr}^{-1}$ ) for male and female respectively. They also found the exploitation rates $(E)=0.67$ for males, and $(E)$ $=0.78$ for females.

Estimation of the relative yield per recruit $\left(Y^{\prime} / R\right)$ indicated that the current exploitation rate is higher than $E_{\max }$ which generates the maximum yield. This result agrees with the findings of Abdullah and Abushusha (2003) who mentioned the overexploitation of tiger shrimp stock in the same area during the year 
2000. Rao, et al., (1993) studied the stock assessment of $P$. semisulcatus off the east coast of India. They stated that in both males and females the landings were lower than the Maximum Sustainable Yield (MSY), estimates although MSY should be realized at a far lower F (0.4 and 0.563) than the present F (1). An analysis of other data on landings of $P$. semisulcatus in the same area indicated that landings exceeded MSY in some years as in 1988 creating a necessity to reduce the effort to maximize landings.

This study recommends the development of a national management strategy for fisheries resources consistent with the international FAO Code of Conduct guidelines. This strategy requires the cooperation between all stakeholders involved in the fisheries sector in order to develop a system for the continuous monitoring and evaluation of the management plan for the justifications and inspection of the fishing gears currently used in the shrimp fisheries.

\section{References}

Abdallah, M. and Abushusha, T.L. (2003) Population dynamics and sustainable exploitation of green tiger shrimp Penaeus semisulcatus in the Jizan area (Southern region of the Saudi Arabian Red Sea coast).
J. Egypt. Acad. Soc. Environ. Develop., (DEnvironmental Studies) Vol.4, No.(2): 65-87.

Abdulqader, E.A.A. (1994) Bionomic patterns of the green tiger shrimp P. Semisulcatus De Haan, In Bahrain waters. A paper presented at Technical Consultation on Shrimp Management in the Arabian Gulf, 6-8 November 1994, Riyadh, Saudi Arabia.

Al-Attar, M. and Ikenouc, M. (1974) Spawning season of shrimp P. semisulcatus in the sea along the coast of Kuwait. KISR, 16p.

Beverton, R.J.H. and Holt, S.J.H. (1956) A review of methods for estimating mortality rates in exploited fish populations, with special reference to sources of bias in catch sampling. Rapp. P. - V. - Re un. CIEM, 140: $67-83$.

Beverton, R.J.H., Holt, S.J. (1957) On the dynamics of exploited fish populations. Fish. Invest. Ser. 2, Mar. Fish. GB Minist. Agric. Fish. Food, (Great Britain), Vol. 19, 533 pp.

Boerema L.K. (1969) The shrimp resources in the Gulf between Iran and the Arabian Peninsula. FAO Fish, Circ 310. pp. 29.

Buqis, A., and Abdulqader, E. A. A. (1993) Identification and some morphometric measurements of penaeid prawns collected during Leg IV of the MT. MITCHELL cruise in the ROPME sea area. Scientific Workshop on results of the $R / V$ MT. MICHELL Cruise. Kuwait, 24-28 Jan. Paper presented at the Fisheries/Plankton Ecology Session. 10p.

Fischer, W. and Blanchiceds, G. (1984) FAO species identification sheets for Fishery purposes. Western Indian Ocean (Fishing Area 51). Prepared and printed with the support of the Danish International 
Development Agency (DANIDA), Rome, Food and Agriculture Organization of the United Nation, Vol (6): pag-Var.

Ghamrawy, M. S. (1988) Some penaeid shrimp species from the Red Sea and the Arabian Gulf, Arab. Gulf J. Scient. Res. Agri. Biol. Sci., B (6):113-128.

Ghamrawy, M. S. (1990) Notes on the Biology of penaeid shrimp at Gizan, Red Sea, J. K. A. U. Mar. Sci., Vol. 1. pp. $67-76$.

Gulland, J.A. (1971) The fish resources of the oceans. West Byfleet, Surrey, Fishing News (Books), Ltd., for FAO, $255 \mathrm{p}$.

Hile, R. (1936) Age and growth of the Cisco Leucichthy artedi (Le Sueur) in the lakes of the North Eastern Highlands, Wisconsim. Bull. U. S. Bur. Fiah., 19: 211 -317 .

Hussain, M. A. M., James, M. B. and Xucai, X. (1996) Population characteristics of green tiger prawns, Penaeus semisulcatus, in Kuwait waters prior to the Gulf War. Hydrobiologia 337: 37-47.

Jones, R. and N.P. van Zalinge (1981) Estimations of mortality rate and population size for shrimp in Kuwait waters. Kuwait Bulletin of Marine Science 2: 273-288.

Le Cren E.D. (1951) The Length-weight Relationship and Seasonal cycle in Gonadal Weight and condition of Perch (Perca fluviatilis) Journal of Animal Ecology, 20: 201- 219.

Metin K., A. Dursun and Tufan E. (1999) Some Biological Aspects of Penaeid Shrimps Inhabiting Yumurtalık Bight in Iskenderun Bay (North-Eastern Mediterranean). Tr. J. of Zoology 23, PP. 53-59.
Mohamed, K.H., El-Musa, M. and Abdul Ghaffar, A.R. (1981) Observation on the Biology of the exploited species of shrimp, Penaeus simesukcatus De Haan, Kuwait Bulletin of Marine Science 2:33-52.

Mohamed, S. and El-Aiatt, A. (2012) Population dynamics and fisheries management of Penaeus semisulcatus exploited by shrimp trawl of Bardawil lagoon, North Sinai, Egypt. Egyptian J. Anim. Prod., 49 Suppl. Issue, Nov. :185-191.

Moreau, J. C., Bambino and Pauly, D. (1986) Indices of overall growth performance of 100 tilapia (Cichlidae) populations, In Maclean, J. L. Dizon L. B. \& Hosillos L. V. (EDS). Proc. First Asian Fish. Forum, Manila, Philippines: 201-206.

Niamaimandi, N., Aziz, A., Siti Khalijah, D., Che Roos, S. and Kiabi, B. (2008) Reproductive biology of the green tiger prawn (Penaeus semisulcatus) in coastal waters of Bushehr, Persian Gulf. ICES Journal of Marine Science, 65: 1593-1599.

PERSGA/GEF (2002) Status of the Living Marine Resources in the Red Sea and Gulf of Aden. PERSGA, Jeddah and the World Bank, Washington, D.C. 134 pp.

Pauly, D. and Soriano, M. L.,(1986) Some practical extensions to Beverton and Holt's relative yield-perrecruit model. Pp. 491-6. In Maclean, J. L., Dizon, L. B. and Hosillo, L. V. (eds.). The first Asian Fisheries Forum. Asian Fisheries Siciety, Manila, Philippines.

Pauly, D. and David, N. (1981) ELEFAN I, a basic program for the objective extraction of growth parameters from length-frequencies data. Meeresforsch., 28(4) : 205 211 .

Pauly, D. (1980) On the interrelationships between natural mortality, growth parameters and mean environmental 
temperature in 175 fish stocks. J. Cons. CIEM, 39 (3):175-192.

Pauly, D. (1981) The relationships between gill surface area and growth performance in fish: a generalization of von Bertalanfy's theory of growth. Meeresforsch., 28 (4): 251-282.

Price, A.R.G. and Jones, D. A. (1975) Commercial and biological aspects of the Saudi Arabian Gulf shrimp fishery. Bull. Mar. Res. Centre. Jeddah. Saudi Arabia. 6: $24 p$.

Rao, P. Vedavyasa (1968) Maturation and spawning of the penaeid prawns of the southwest coast of India. FAO Fish.Rep., (57) Vol. 2:285-304.

Rao, G.S., Subramaniam, V.T., Rajamani, M., Manickam, P.E.S. and Maheswarudu, G. (1993) Stock assessment of Penaeus spp. off the east coast of India. Indian Journal of Fisheries, 40 (1,2): 1-19.

Shaikhmahmud, F.S. (1961) A brief account of the changes in the developing ovary of penaeid prawn Parapenaeopsis stylifera (M.Edw.) in relation to maturation and spawning cycle. J. Univ. Bombay, 29(3-5):62-77.

Van Zaling, N.P. (1984) The shrimp fisheries in the Gulf between Iran and the Arabian peninsula, pp. 71-83. In J. A. Gulland and B. J. Rothschild (eds) Penaeid shrimps: Their Biology and Management. Fishing News Books Ltd., Surrey, England.

Zaki, M.I.; Abu Shabana M.B. and Assem, S.S. (1995) The reproductive biology of the saddled bream (Oblada melanura, L. 1758) from the Mediterranean coasts of Egypt. OEBALIA, vol. XXI: 17-26. 
دراسة بيولوجية لروبيان ام نعيرة (بينيوس سميسلكيتس) في مصائد منطقة جازان ( البحر الاحمر ، المملكة العربية السعودية )

\section{لافي السلمي ، حسن جستنيه}

كلبة علوم البحار- قسم الاحياء البحرية ـ جامعة الملك عبدالعزيز - جده ـ المملكة العربية السعودية

المستخلص: اجريت هذه الدر اسة للتحقق من الجو انب البيولوجية لربيان ام نعيرة - النمر الاخضر (بينيوس

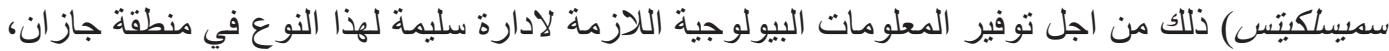

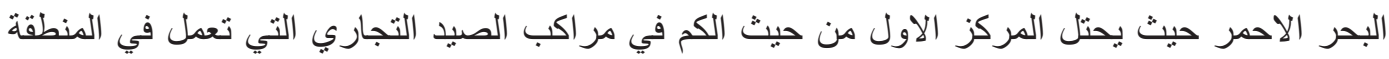

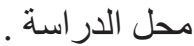

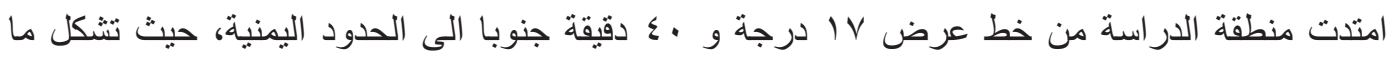

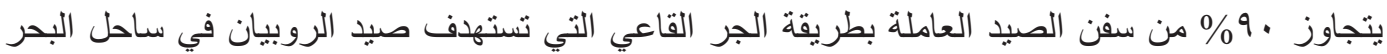

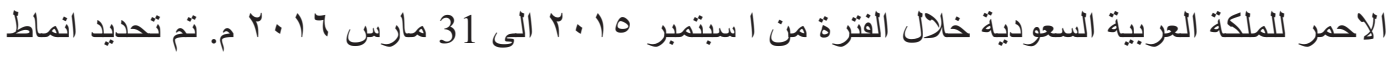
النمو و المعاملات المرتبطة للأكور و الاناث.

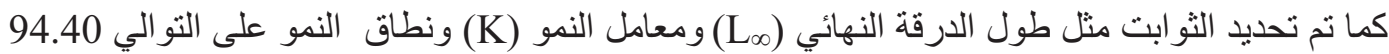

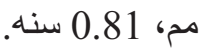

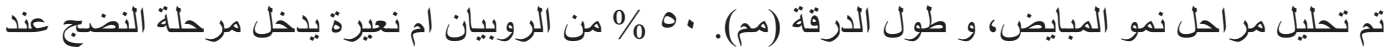

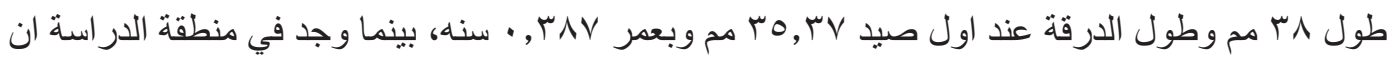

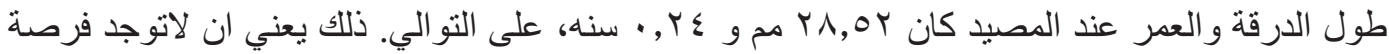

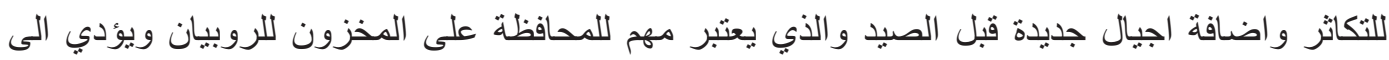
الصيد الجائر.

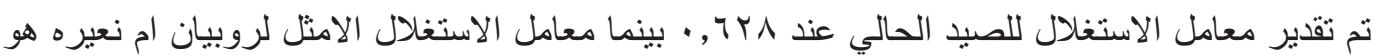

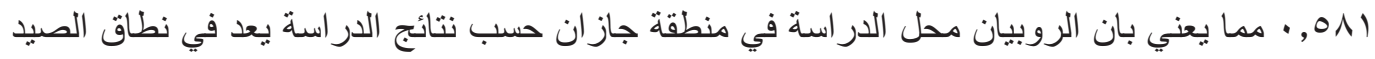

